\title{
Going beyond Sorting Waste into Different Bins: Responsible Production and Consumption of Toys
}

\author{
Kwok Shing Wong \\ Department of Early Childhood Education, The Education University of Hong Kong, Hong Kong, China \\ Email: kswong@eduhk.hk
}

How to cite this paper: Wong, K. S. (2018). Going beyond Sorting Waste into Different Bins: Responsible Production and Consumption of Toys. Creative Education, 9, 442-455. https://doi.org/10.4236/ce.2018.93031

Received: February 12, 2018

Accepted: March 24, 2018

Published: March 27, 2018

Copyright $\odot 2018$ by author and Scientific Research Publishing Inc. This work is licensed under the Creative Commons Attribution-NonCommercial International License (CC BY-NC 4.0). http://creativecommons.org/licenses/by-nc/4.0/

\begin{abstract}
Exposing children to concepts about sustainable development (SD) can be challenging because children might lack the life experience and the right levels of linguistic and cognitive skills to understand the complex issues surrounding SD. Coupled with other factors such as the teacher's professional knowledge and limited teaching time available, the teaching of SD might become operationalised as the sorting of waste products into different types of bins in the early childhood curriculum. Using a single case study, I examined how a Hong Kong kindergarten empowered young children to contribute to sustainable development through targeting the production and consumption of an object type that is readily understood by children: toys. Based on classroom observations involving three age groups (K1: three-year-olds; K2: four-yearolds; K3: five-year-olds) and interviews with the principal, I found that the school had creatively adopted a whole school approach in order to support children's gradual learning about sustainable development. At K1 the focus was on refusal: avoiding plastic toys in learning activities. At K2 the focus was on reuse. Knowledge related to the responsible production and consumption of toys was directly taught. At K3, the focus was on change: the children were to apply their previously acquired knowledge by producing toys for all children to share. Analyses of the interview data also revealed that going beyond the school level by partnering with parents in sustainable development had consequences for the school and the wider community.
\end{abstract}

\section{Keywords}

Sustainable Development, Kindergarten, Hong Kong, Toys

\section{Introduction}

In 2015 world leaders adopted 17 Sustainable Development Goals (SDGs) of the 
2030 Agenda for Sustainable development (SD) at a United Nations' summit with a view to fostering development that "meets the needs of the present without compromising the ability of future generations to meet their own needs." These 17 goals cover the domains of economic growth, social inclusion, and environmental protection. Specifically, there was the recognition that the three inter-related domains could co-exist in harmony. Building economic growth and addressing social issues do not have to come at the expense of the environment (See UN, 2017 and UNESCO, 2005 for details). This change in mindset may encourage creative solutions to economic and social problems while taking into account the need to minimize the damage to the environment.

Changing people's beliefs requires more than the introduction of SDG-related legislation. Education is the key to promoting SDG. Without acknowledging the current discord between economic development, social needs and environmental protection and the consequences of this discord, it is difficult for humankind to understand where our obligations and responsibilities lie in safeguarding the interests and needs of future generations. Because early childhood represents the formative period in which important attitudes, values and behaviours relevant to sustainable development emerge (see Davis, 2009), it is important to expose young children to sustainable development.

Educating children about SDGs does not come without challenge. First, children might be limited by their cognitive abilities or their life experiences (see Engdahl, 2015; Kahriman-Ozturk, Olgan \& Guler, 2012; Palmer, Suggate, \& Grodzinska-Jurczak, 2003; Reunamo \& Suomela, 2013) in their inquiries into SDG-related topics (e.g. climate change, global warming). Second, teachers might lack the professional knowledge and skills relating to the promotion of SDGs (Ravindranath, 2007; Summers, Corney \& Childs, 2003). In my own observations in Hong Kong kindergartens, teachers often operationalise the teaching of sustainable development as sorting waste into different recycling bins. This practice is problematic because children may get the idea that as long as waste can be recycled, no drastic change is required in the way commercial goods are produced and consumed. What has been missing is a clear emphasis on the hierarchy of the different ' $R$ 's: reduce, reuse (and refuse) are more important than recycling. This is because many materials cannot be recycled. Most materials that are recycled today are downgraded in the process and, for some materials, recycling is more energy intensive than new production (see Allwood, 2014). Treating recycling as the last option is particularly relevant to goal \#12 of sustainable development: responsible production and consumption (UN, 2017). For example, by encouraging people to bring their own water bottles for water refill, fewer plastic bottles of water would need to be produced and there would be a reduced need for bottle recycling. Finally, when a school's curriculum is tight, even teachers with relevant SDG knowledge and skills might lack time to implement a full-fledged, co-ordinated SDG curriculum.

A review of existing studies showed that there were not many studies that 
examined how SDGs are introduced in the early childhood setting, despite the consensus on the need for an early exposure (see Davis, 2009 and Kahriman-Ozturk, Olgan, \& Guler, 2012 for a review). In this study I therefore sought to enrich the current research base by investigating how a Hong Kong kindergarten contributed to children's understanding of sustainable development. I specifically focussed on SDG goal \#12: responsible production and consumption. This goal becomes concrete for children, and does not go beyond the children's current linguistic and cognitive knowledge, when it is studied in the context of toys: objects that children are engaged with on a regular basis at home and at school.

\subsection{Why Toys?}

Toys are an important starting point for children to learn about responsible production and consumption. Despite their educational value and contribution to different aspects of child development (Goldstein, 1994), toys leave a non-negligible footprint on the environment during their production, distribution and disposal.

Production. Most toys are made of plastics which originate from fossil fuels, and the packaging materials that come with the toys (e.g. cardboard) further strain the world's resources. A lot of these packaging materials end up in landfill (see Thompson, Moore, Vom Saal, \& Swan, 2009). Also, the plastic toys themselves may contain harmful chemicals, such as phthalates (Bouma \& Schakel, 2002), and are therefore unsuitable for recycling (see also Guzzonato, Puype, \& Harrad, 2017; Ionas, Dirtu, Anthonissen, Neels, \& Covaci, 2014; Stringer, Labunska, Santillo, Johnston, Siddorn, \& Stephenson, 2000).

Distribution. Because toys are now mainly produced in countries with low labour costs, shipping toys to the target countries will incur transportation costs. This means more fossil fuels are burnt, unless biodiesel is used (see Demirbas, 2007 for the importance of biodiesel).

Disposal. Most modern toys are not easy to recycle. They contain multiple materials. Besides plastics, there may be metal, textile fibres, batteries, circuit boards, etc. (Solé, Watson, Puig \& Fullana-i-Palmer, 2012). The sorting of these different component materials usually makes recycling economically non-viable.

If toys were only produced in limited quantities and were shared across children, environmental damage associated with toys could be limited. However, worldwide figures for spending on toys paint a gloomy picture. The average amounts spent on toys per child in 2015 were 500 USD, 499 USD, 482 USD and 379 USD for Australia, United Kingdom, United States and Japan respectively (Statista, 2017). If these toys cannot sustain children's interests for long and are soon discarded, their disposal will become a burden for the environment. Also, spending on toys was greatest when children were under the age of 6 (Kornrich \& Furstenberg, 2013). To prevent children from unknowingly becoming participants in causing damage to the environment, it is important to help young chil- 
dren understand that they can contribute to sustainable development through changing the ways toys are produced and consumed. Because school is a major setting where children acquire important knowledge, values and skills (Hong Kong Education Bureau, 2017), studying how schools empower children to contribute to sustainable development is urgently needed.

\subsection{Why a Hong Kong Kindergarten?}

Hong Kong makes a useful site of research, because as a Special Administrative Region (SAR) of the People's Republic of China (PRC), what it does is likely to serve as a reference standard for other cities in the PRC. Although the PRC's average spending on toys was relatively low (52 USD) compared to countries such as Australia in 2015 (Statista, 2017), further economic development taken together with its vast population will inevitably lead the figure to increase considerably in the future. Other reasons include: first, similar to other major international financial centres, Hong Kong's economy relies mainly on service industry. There is not enough local manufacturing industry to support the building of recycling facilities. Currently, most recyclable waste is shipped outside the territory. Because offshore recycling facilities may refuse to accept recyclable waste from Hong Kong (SCMP, 2017), it is useful to study how waste issues are dealt with in the education system here. Second, Hong Kong kindergartens are known to have a demanding curriculum. Children are required to learn three spoken languages (Cantonese, English and Putonghua) and two written languages (Chinese and English). Together with other learning domains stipulated in the Kindergarten Education Curriculum Guide (e.g. physical fitness and health, self and society, arts and creativity, etc.) (Hong Kong Education Bureau, 2017), kindergartens would need ingenuity to incorporate the teaching of sustainable development in their curriculum normally limited to a half day programme (3 hours). A study into how Hong Kong kindergartens achieve this will provide important insights on how to introduce sustainable development in the early childhood context under not so favourable conditions.

\subsection{The Current Study}

Because promoting sustainable development requires a whole-school approach (see Wang, 2015), in this study I examined how my target SDG, responsible production and consumption, was introduced across the different age levels in a kindergarten. Because principals play a vital role in overseeing the school's curriculum, I was interested in the strategies deployed by the principal in the target school to make the implementation of SDGs easier. Based on classroom observations and also interviews with the principal (see Methods for details), I gathered information in order to answer the following two research questions:

(1) How did the target school embed the teaching of responsible production and consumption of toys in the school's curriculum?

(2) Beyond classroom strategies, what other strategies were deployed by the 
school to contribute to the cause of sustainable development?

\section{Methods}

\subsection{Participating School}

Hong Kong Soka Kindergarten, founded in 1992, is a non-profit making kindergarten that has joined the free quality kindergarten education scheme in Hong Kong. It has 11 classrooms, large indoor and outdoor play areas. Currently it has 42 staff members, and over 600 children are enrolled in the school. In 2016, 39 of the staff were qualified kindergarten teachers (possessing a certificate in early childhood education or above) and 31 were degree holders. The school adopts a play-based constructivist approach in its teaching of the six learning domains required by the Hong Kong Government: physical fitness and health, language, early childhood mathematics, nature and living, self and society, and arts and creativity. The school met all the prescribed standards in the quality assurance framework employed by the Hong Kong Education Bureau in the last review exercise in 2013. The school's performance was highly rated by the Government's inspection team (see Hong Kong Education Bureau, 2013 for details). According to the principal, over $80 \%$ of the children's parents are white-collar workers or professionals. I chose this school because it has acquired the reputation of being a "green" kindergarten in the Hong Kong early childhood education scene.

\subsection{Data Collection}

My data came from two main sources: fieldnotes obtained from my classroom observations, and post-visit meetings with the school principal.

Classroom Observations. A two-day classroom visit was organized in November 2017. Each day I spent two and a half hours inside the target classrooms in order to examine (1) the teaching content that was directly related to responsible production and consumption; and (2) strategies that the whole school employed in order to sustain children's learning about their relationships with the environment. In total, four classrooms across three age levels were observed: 1 $\mathrm{K} 1$ classroom (serving children aged between three and four years of age), $1 \mathrm{~K} 2$ classroom (serving children aged between four and five years of age) and $2 \mathrm{~K} 3$ classrooms (serving children aged between five and six years of age). In each classroom, there were 28 children with three teachers. On the dates of the visits, the topic of inquiry, as it happened, was toys in the $\mathrm{K} 2$ classroom. The topic for $\mathrm{K} 1$ was picnics. The K3 classrooms were special because each classroom had a unique topic: one class focused on food, while the other focused on housing. Fieldnotes were taken during the observations.

Because of the nature of my study, I did not provide any input on or feedback to the teaching content during the visits in order not to interfere with the way the teachers structured their learning activities. Occasionally however I interacted with the teachers and the children because, encouraged by the teachers, the children sometimes explained to me what the whole class was exploring. 
Post-visit Meetings with the Principal. Because the principal oversees the articulation of the school's curriculum across the three kindergarten age levels, I interviewed her upon the completion of the visits. Due to time constraints, there were two meetings, in conjunction with communication using Whatsapp. In the first interview (lasting for about 30 minutes), I started off by summarizing what I had observed in the lessons in order to verify with the principal the accuracy of my observations. This was followed by inviting the principal to comment on the same lessons. In the second interview (lasting for about 20 minutes), the focus was on the school's strategies to promote sustainable development beyond the level of school. Specifically, did the school engage the parents and the wider community?

\subsection{Reliability of the Data}

To ensure the content of my fieldnotes was accurate, I verified my observations with the teachers involved on two occasions: after the 2-day school visit, and during a teacher training seminar that I offered to the school. I also verified the fieldnotes' content with the principal in the interviews.

\section{Results and Discussion}

Table 1 presents a summary of my classroom observations. The observations indicate that both direct and indirect instruction strategies were used for the teaching of responsible production and consumption. Also, there was a progression in the way the topic was introduced to the children.

Instruction strategies. In the K2 classrooms, direct instruction strategies were used. Specifically, the teachers explored with the whole class a topic of inquiry directly related to sustainable development: how can young children, despite their age, contribute to environmental protection through responsible ways to produce and consume toys? The series of learning activities had two target outcomes: (1) to help children understand that they can "save the planet" by playing with toys made from waste; and (2) to help children understand that reducing the overall consumption of self-made toys through sharing can also "save the planet". These two outcomes were achieved. For the first outcome, two four-year-old children came to me spontaneously and explained to me the materials used for making their favourite toy of the week: the football board game (Figure 1). This showed that the children were aware that toys could be made from recyclable materials and also, that they could derive as much fun from these self-made toys as from commercially available toys. With respect to the second outcome, the children took turns to play with the toys. During the whole visit, despite the popularity of the self-made toys, I did not hear the children voicing their need to have multiple copies of the same toys. The children simply waited for their turn or visited some other learning corners first. This strategy of sharing resources has drastically reduced the number of toys physically present in the classroom. 
Table 1. Summary of classroom observations.

\begin{tabular}{llll}
\hline Class & \multicolumn{2}{c}{ Particulars } & \\
\cline { 3 - 4 } levels & Theme & Observations & Analyses
\end{tabular}

Originally the children were supposed to go to the public playground opposite the school in order to have a picnic. But because of rain, the picnic and the associated extension activities were conducted inside the children's classroom. A ground sheet made of plastic was laid on the floor to designate the area for the picnic. Instead of using props for the picnic (e.g. plastic food), the teachers had asked the children's parents beforehand to prepare real food K1 Picnic and place the food items inside the children's lunchboxes. Junk food was discouraged for health reasons and also because of the often bulky packaging materials that come with such food.

During the in-class picnic, the children learnt about what types of food they could enjoy in a picnic (different children had different food), activities that they could do (e.g. it is alright to chat with one another in a picnic), and rules that the children need to pay attention to (e.g. clean up your own mess afterwards).

It was a free-play session. The children were free to visit the various learning corners in the classroom. One of the corners was the toy corner. Instead of seeing commercially available toys, the toys in the corner were all self-made. There were football board games (Figure 1) and vending machines from which you can get "surprises" (Figure 2): plastic eggs which contain small toy items. The football board game was made from a shoebox, disposable chopsticks, old clothes pegs, and a paper football. The clothes pegs served as the football players and were attached to the chopsticks. By rolling the chopsticks, the football players would "kick" the paper football to one of the goals. The vending machines were created from boxes with compartments inside. By turning a knob made from the cardboard part of a toilet roll, previously discarded plastic eggs with toys inside would roll out from the machines. All the construction materials for the toys were previously "waste" materials which would have otherwise gone to landfill. The children were not supposed to play on their own. During the visit, there were always two to three children being engaged with one of these self-made toys. Although there were children waiting to play with the self-made toys, the children were happy to wait for their turn.

It was a free-play session. The children were free to visit the various learning corners in the classroom. One of the corners was a snack store. This corner displayed different snacks that were made from recyclable materials. In this corner activity, K3-a Food some children pretended to be the customers, while others pretended to be the staff of the snack store. The customers needed to rate the service provided by staff on a feedback form. The staff member with the highest rating would get a reward.
1) Children learnt about the differences between real food and plastic toy food: some children dropped their food on the floor. Normally in an imaginative play situation involving plastic food, children would simply pick up the food and pretend to eat it again. But the teachers explained to the children that the real food got soiled, and the children learnt that real food would go to waste if they were not careful with it.

2) Because real food rather than plastic toy food was used, there was a wider variety of food items present in the classroom. Also, because the food was all consumed by the end of the learning activities, there was no need for the school to sterilize or store any plastic food items. 3) Although the groundsheet was made of plastic, it was easy to clean and the sheet was used repeatedly by different groups of children on the same day.

1) Although the self-made toys themselves may not look as "attractive" as commercially available toys, the children were happily playing these toys with their friends. The engagement with the toys was sustained and lasted for at least 5 minutes for each group of 2 to 3 children. In other words, self-made toys can sustain children's attention because of the children's special attachment towards them.

2) Because the toys were not as strong as plastic toys, every now and then some parts fell off from the toys. This happened twice in the observations. Instead of going to the teachers for help, the children tried to repair the toys by putting the parts together again. This showed that the children were using strategies to "prolong" the lives of their toys so that they would not need to dismantle the toys and put the various components into different recycling bins.

3) The fact that the children did not ask for more self-made toys showed that the children can put aside their immediate needs (i.e. "I want to play with the toy now."). This is an important first step towards responsible consumption.

1) There was an avoidance of plastic toys. Although the self-made snacks might be less "realistic" than plastic snack items, the children enjoyed the activity. 3 to 4 children played in this snack store area each time. 2) The children were not rough with their self-made snack food items. A child commented, "It (pointing to the snack) might fall apart. So I need to be more careful." This showed that the children had an understanding of the need to conserve resources. Instead of thinking about "getting a replacement", the children took great care in preserving their toys so that no replacement was needed. 


\section{Continued}

It was a free-play session. The children were free to visit the various learning corners in the classroom. One of the corners was the children's artwork corners. This corner displays the dream houses made by the children in order

K3-b Housing to encourage peer learning. These houses were previously featured in a show and tell session where the children were to talk about their creation. The construction materials for these houses were all waste materials. Following this peer learning task, the children had to complete a recording form about their dream houses.
1) No plastic blocks were used in the construction of the dream houses. The children simply gave lives to cardboard boxes and shoe boxes that would have otherwise gone to waste. Some children had taken great care to create a staircase using paper so that there could be two levels in the house.

2) Language and literacy activities were embedded in the activities. Children learnt vocabulary items (e.g. names of materials, names of objects found in different rooms of a house) relating to their dream houses. By integrating the teaching of "reuse" with language, precious curriculum time was saved.

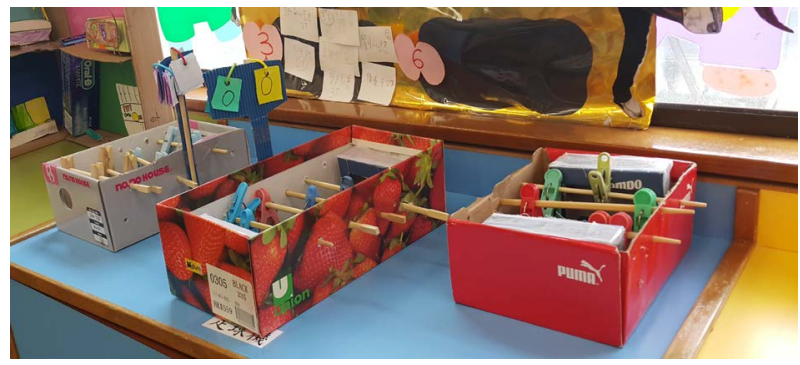

Figure 1. Football board games.

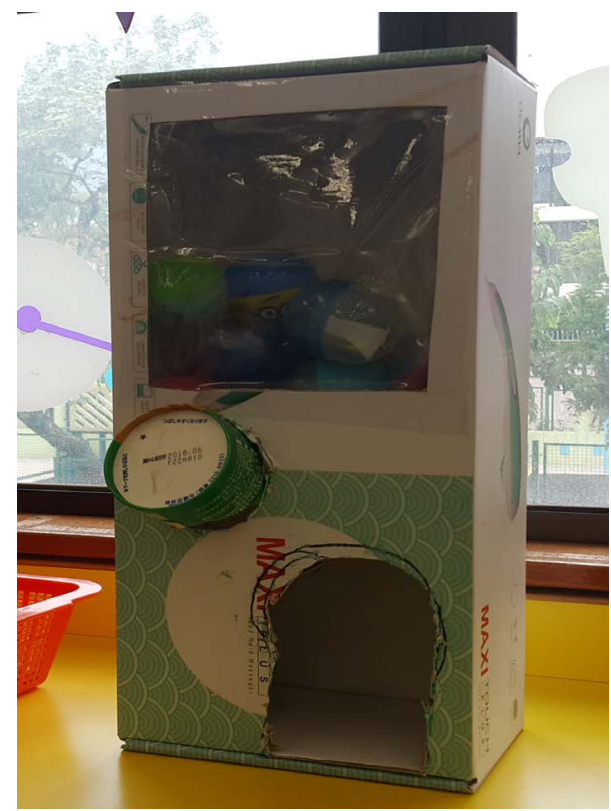

Figure 2. Vending machines.

In the $\mathrm{K} 1$ and $\mathrm{K} 3$ classrooms, indirect strategies were used. Although the topics of inquiry were not directly related to the responsible production and consumption of toys, the children learnt that they could contribute to sustainable development by reducing the overall use of non-recyclable props in their learning inquiries. First, there was an avoidance of plastic toy items. Real food was used in the K1 picnic activities, whereas recyclable paper and cardboard (rather 
than plastic LEGO pieces) were used for making dream houses in K3. Second, the teachers emphasized the need to share and protect common resources. In the $\mathrm{K} 1$ class, the teachers explained to the children that everyone must help clean the plastic ground sheet because the sheet would be used again by the next group of children (rather than going into the bin). Subsequently some children (5 out of a group of 14 children) helped remove food debris from the ground sheet (note: the other children did not do so because they were still eating their food). This shows that the activity has helped some children to acquire a rudimentary understanding of the principle that their enjoyment (of the picnic) should not come at the expense of "future generations" (i.e. the next group of 14 children). In the $\mathrm{K} 3$ classes, I asked the teachers whether parents would find it problematic that different classrooms had different topics of inquiry. The teachers explained that the idea of a floating classroom is used at K3. After a week of inquiry, the children from one class will move to the next classroom. Several birds are killed with one stone: first, this cuts down the amount of classroom decorations and self-made toys for the whole form. Second, the children can learn about what children from other classrooms have inquired. Finally, having to share common resources is a good way to teach children the importance of conserving resources. A class teacher remarked, "If the children are not careful with the toys made by children from a different class, things may come around. The children are aware of the consequences of not being nice to other children's toys."

Another important observation is that in the school there was a large arts and craft area in which the materials were shared by all the children in the school. Most of the materials present in the area were recyclable materials or natural objects. According to the teachers, these materials were collected by the children from home. For the children, it was an important learning opportunity because the children had to work out with their family members what materials would be suitable for bringing to the school (e.g. plastic bottle caps that have been washed) and which would be unsuitable (e.g. paper that has been soiled by food). Also, the teachers believed that whilst arts and craft activities can promote children's aesthetic development and fine-motor control, these benefits should not come at the expense of the environment on a regular basis. "There are over 600 children. Because we avoid commercially available arts and craft materials, the children are contributing to protecting world resources, and the school also saves its spending on materials for arts activities. The saved expenses can be channelled to other important uses."

Together these direct and indirect instruction strategies help children understand the importance of responsible production and consumption of toys, and help children develop a habit of protecting the environment.

Developmental Progression. The observations revealed a clear progression in the way responsible production and consumption is taught in the school. At K1, the focus was on exposure: to help children become aware that they can play with real objects or self-made toys constructed from recyclable materials. The 
children can refuse to play with commercially available toys. At K2, the children were taught directly how they can protect the environment by changing their behaviour in relation to their consumption of toys. Specifically, materials can be given a new purpose and turned into toys. At K3, the curriculum emphasized change: what can children do to reduce not just their own, but all children's consumption of toys? The data showed that the school had taken great care in ensuring that the learning content is "down to the children's level"- not beyond the children's life experience, current cognitive and linguistic knowledge.

Besides examining instructional strategies, I was interested in how the school might have engaged with parents and the wider community to contribute to the cause of responsible production and consumption. An analysis of the interview data with the principal has revealed three themes.

Involve the parents. Initially I had the impression that the self-made toys in the $\mathrm{K} 2$ classroom were made jointly by the teachers and the children in the class. But the principal subsequently explained that most self-made toys in the different classrooms were made jointly by the (older) K3 children (aged five) and their parents during the three long holidays (Mid-autumn festival, Easter and Christmas) in the academic year. There are three K3 classes in the school, and the children in each class are responsible for making toys with their parents in one of the long holidays. In this way there is a gradual supply of these self-made toys and the school does not need too much space to store these toys. Also, the parents are not overburdened because they only need to make toys once.

The school's ultimate goal was to change the mindset of the parents. There are a few reasons why the principal thought this goal to be important. First, parents are important role models for their children. According to the principal, "If the parents are not environmentally conscious, the children might be confused because of the different message that they receive from school. By encouraging the parents to adopt a more environmentally friendly life style through making toys from recyclable materials, the children will feel that their parents love the environment, and the children will want to do the same." Second, because children do not have the purchasing power to buy toys, it is more important to "educate the parents that their children can play happily with self-made toys created from items which would otherwise go to waste". Third, some parents may mistakenly think that buying new toys for their children may forge a closer "bond" between the children and themselves. Also, because many of the parents in the school are young parents and young parents tend to buy more toys for their children than older parents (Kim, 2002), the school thought that these parents should be encouraged to jointly make toys with their children.

The school believed that even if this joint parent-child activity cannot change the mindsets of all parents, at least, the parents will spend more time with their children, and the parents may think twice next time when they are in a store wanting to buy toys for their children.

Involve the children in the toy distribution process. The principal explained 
that after the toys were produced in the long holiday in October, the K3 children were to distribute their self-made toys to different classrooms across the three age levels. This act was empowering for all the children. For the K3 children, they knew that the absence of packaging materials for toys came with a risk. The toys might become damaged during the transportation and delivery process, but the reward was that they were able to save the environment by not wasting any materials required for packaging, and also by reducing other children's needs to consume commercially available toys. Also, the principal added, "normally children do not want to part with the toys that they have made because they see these toys as their private possessions. They feel that saying goodbye forever to their own toys is bad. But by involving the children directly in the distribution process, the givers will see with their own eyes the happiness of the recipients and experience first-hand the joy of sharing. The children will feel that it is not so bad to part with their own toys after all."

For the younger children (the K1 and K2 children), besides learning that toys do not have to be purchased from toy stores, they saw the $\mathrm{K} 3$ children as their role models. They would realize that once they become K3 children themselves, they would do the same by making toys for other children's enjoyment.

Redistribute resources from home to the wider community. Some parents in the school understand that as a non-profit-making kindergarten, more resources being spent on purchasing educational toys would mean less resource for hiring and retaining high calibre teachers and for these teachers' professional development. So there has been a culture for the parents to donate to the school toys that they no longer need. The school will check whether the toys received are suitable for use inside school. Any toys in excess will subsequently be donated to NGOs so that the toys could be redistributed to children in need. Whilst the use of old toys in school means that there may be visible wear-and-tear in the toys that are present in the classroom, the children do not mind, and are happily playing with these toys that once belonged to somebody else.

The interview data showed that to effectively promote sustainable development, schools might need to go beyond the whole-school approach (see Wang, 2015 for different approaches towards sustainable development). Garnering the support of parents is vitally important in ensuring that parents will not be inadvertently doing something that contradicts what their children learn at school. Also, by partnering with NGOs, a school can help contribute to responsible production and consumption through redistribution of toys.

\section{Conclusion}

This study began with examining how a Hong Kong kindergarten engaged young children to contribute to sustainable development. Both direct and indirect instruction strategies were observed in the classrooms, and there was a clear progression in the way the school exposed the children to aspects of sustainable development. At $\mathrm{K} 1$, the focus was to expose children to the concept that they 
can play with real objects or self-made toys constructed from recyclable materials. At K2, the children were taught directly how they can protect the environment by changing their behaviour relating to their consumption of toys. At K3, the focus was on implementation beyond the individual level: what can children do to reduce not just their own, but all children's consumption of toys? Besides observing the coordinated use of instruction strategies, I also noted the importance of leadership in inspiring the whole school and coordinating with multiple partners in order to contribute to sustainable development. Instead of relying on teachers' own initiatives, the principal adopted a whole school approach to ensure that the SDG-related learning and teaching activities in school are coordinated and are presented in ways appropriate to the children's age and cognitive levels. Also, by partnering with parents and NGOs, the school was able to channel resources from home to school and then from school to the wider community, creating an impact beyond the level of school.

Whilst this study affords useful insights on how a school might engage young children to contribute to sustainable development, I want to highlight some limitations in this study. First, children are important stakeholders of education, but this study primarily focused on the perspective of the school in dealing with the topic of responsible production and consumption. Future studies should take the voice of children into account by studying in detail children's views of sustainable development, and whether their learning experience at school has in any way changed their behaviour at home. Second, the school's success was in part due to parents' support. In school settings where parents are less involved in the education of their children, it might be very difficult or impossible to require children to jointly create with their parents toys that can be brought to school for all children to share. Future studies should expand the scope of this current study by researching into school settings with less involved parents. Finally, because electronic toys are playing an increasing role in the lives of kindergarten children, future studies may focus specifically on the responsible production and consumption of electronic toys (Levin \& Rosenquest, 2001).

\section{Acknowledgements}

I would like to thank Principal Naomi Lam and all of the staff and children from Hong Kong Soka Kindergarten for having made this study possible. I also want to thank the anonymous reviewers and editors for their valuable comments.

\section{References}

Allwood, J. M. (2014). Squaring the Circular Economy: The Role of Recycling within a Hierarchy of Material Management Strategies. In Handbook of Recycling (pp. 445-477). Amsterdam: Elsevier. https://doi.org/10.1016/B978-0-12-396459-5.00030-1

Bouma, K., \& Schakel, D. J. (2002). Migration of Phthalates from PVC Toys into Saliva Simulant by Dynamic Extraction. Food Additives \& Contaminants, 19, 602-610. https://doi.org/10.1080/02652030210125137

Davis, J. (2009). Revealing the Research "Hole" of Early Childhood Education for Sustai- 
nability: A Preliminary Survey of the Literature. Environmental Education Research, 15, 227-241. https://doi.org/10.1080/13504620802710607

Demirbas, A. (2007). Importance of Biodiesel as Transportation Fuel. Energy Policy, 35, 4661-4670. https://doi.org/10.1016/j.enpol.2007.04.003

Engdahl, I. (2015). Early Childhood Education for Sustainability: The OMEP World Project. International Journal of Early Childhood, 47, 347-366. https://doi.org/10.1007/s13158-015-0149-6

Goldstein, J. H. (Ed.) (1994). Toys, Play, and Child Development. Cambridge: Cambridge University Press. https://doi.org/10.1017/CBO9780511527616

Guzzonato, A., Puype, F., \& Harrad, S. J. (2017). Evidence of Bad Recycling Practices: BFRs in Children's Toys and Food-Contact Articles. Environmental Science: Processes \& Impacts, 19, 956-963. https://doi.org/10.1039/C7EM00160F

Hong Kong Education Bureau (2013). Quality Assurance Framework: Inspection Report for Hong Kong Soka Kindergarten.

http://www.edb.gov.hk/attachment/tc/edu-system/preprimary-kindergarten/quality-as surance-framework/qr/qr-report/HKSoka.pdf

Hong Kong Education Bureau (2017). Kindergarten Education Curriculum Guide. http://www.edb.gov.hk/attachment/en/curriculum-development/major-level-of-edu/pr eprimary/KGECG-En-Draft-2017.pdf

Ionas, A. C., Dirtu, A. C., Anthonissen, T., Neels, H., \& Covaci, A. (2014). Downsides of the Recycling Process: Harmful Organic Chemicals in Children's Toys. Environment international, 65, 54-62. https://doi.org/10.1016/j.envint.2013.12.019

Kahriman-Ozturk, D., Olgan, R., \& Guler, T. (2012). Preschool Children's Ideas on Sustainable Development: How Preschool Children Perceive Three Pillars of Sustainability with the Regard to 7R. Educational Sciences: Theory and Practice, 12, 2987-2995.

Kim, M. (2002). Parents' Perceptions and Behaviors Regarding Toys for Young Children's Play in Korea. Education, 122, 793-808.

Kornrich, S., \& Furstenberg, F. (2013). Investing in Children: Changes in Parental Spending on Children, 1972-2007. Demography, 50, 1-23.

https://doi.org/10.1007/s13524-012-0146-4

Levin, D. E., \& Rosenquest, B. (2001). The Increasing Role of Electronic Toys in the Lives of Infants and Toddlers: Should We Be Concerned? Contemporary Issues in Early Childhood, 2, 242-247. https://doi.org/10.2304/ciec.2001.2.2.9

Palmer, J. A., Suggate, J., \& Grodzinska-Jurczak, M. (2003). Thinking about Waste: Development of English and Polish Children's Understanding of Concepts Related to Waste Management. European Early Childhood Education Research Journal, 11, 117-140. https://doi.org/10.1080/13502930385209201

Ravindranath, M. J. (2007). Environmental Education in Teacher Education in India: Experiences and Challenges in the United Nation's Decade of Education for Sustainable Development. Journal of Education for Teaching, 33, 191-206.

https://doi.org/10.1080/02607470701259481

Reunamo, J., \& Suomela, L. (2013). Education for Sustainable Development in Early Childhood Education in Finland. Journal of Teacher Education for Sustainability, 15, 91-102. https://doi.org/10.2478/jtes-2013-0014

Solé, M., Watson, J., Puig, R., \& Fullana-i-Palmer, P. (2012). Proposal of a New Model to Improve the Collection of Small WEEE: A Pilot Project for the Recovery and Recycling of Toys. Waste Management \& Research, 30, 1208-1212.

https://doi.org/10.1177/0734242X11434563 
South China Morning Post (SCMP) (2017). Shift in Mainland Policy Could Spell Disaster for Hong Kong Recycling.

http://www.scmp.com/news/hong-kong/health-environment/article/2110238/shift-mai nland-policy-could-spell-disaster-hong

Statista (2017). Average Spend per Child on Toys Worldwide in 2015, by Country (in U.S. Dollars).

https://www.statista.com/statistics/750787/global-toy-market-average-spend/

Stringer, R., Labunska, I., Santillo, D., Johnston, P., Siddorn, J., \& Stephenson, A. (2000). Concentrations of Phthalate Esters and Identification of Other Additives in PVC Children's Toys. Environmental Science and Pollution Research, 7, 27-36.

https://doi.org/10.1065/espr199910.007

Summers, M., Corney, G., \& Childs, A. (2003). Teaching Sustainable Development in Primary Schools: An Empirical Study of Issues for Teachers. Environmental education research, 9, 327-346. https://doi.org/10.1080/13504620303458

Thompson, R. C., Moore, C. J., Vom Saal, F. S., \& Swan, S. H. (2009). Plastics, the Environment and Human Health: Current Consensus and Future Trends. Philosophical Transactions of the Royal Society B: Biological Sciences, 364, 2153-2166. https://doi.org/10.1098/rstb.2009.0053

UNESCO (United Nations Educational, Scientific and Cultural Organisation) (2005). United Nations Decade of Education for Sustainable Development (2005-2014). http://unesdoc.unesco.org/images/0014/001416/141629e.pdf

United Nations (UN) (2017). Sustainable Development Goals. http://www.un.org/sustainabledevelopment/sustainable-development-goals/

Wang, W. (2015). An Exploration of Patterns in the Practice of Education for Sustainable Development in China: Experience and Reflection. Open Journal of Social Sciences, 3, 64. https://doi.org/10.4236/jss.2015.35010 